\title{
ANALISIS DETERMINAN PREMENSTRUAL SYNDROME (PMS) TERHADAP WANITA USIA PRODUKTIF DI POLI OBSTETRI DAN GYNEKOLOGY RUMAH SAKIT MUHAMMADIYAH PALEMBANG TAHUN 2015
}

\author{
Nistiani \\ Akademi Kebidanan Persada Palembang
}

A B S T R A K

Informasi Artikel :

Diterima : April 2018

Disetujui : Mei 2018

Dipublikasikan : Juni 2018

Beberapa waktu sebelum menstruasi, sejumlah gadis dan wanita biasanya mengalami kumpulan gejala fisik, psikologis dan emosi yang terkait dengan siklus menstruasi wanita sebelum datang bulan atau istilah populernya Premenstrual Syndrome (PMS). Gejala yang sering dirasakan adalah nyeri payudara, rasa penuh atau kembung di perut bagian bawah, merasa sangat lelah, nyeri otot, terutama di punggung bagian bawah atau perut, perubahan kebasahan vagina atau tumbuh jerawat dan emosi yang

*Korespondensi Penulis : Nestiani@rocketmail.com sangat kuat.Angka kejadian premenstrual syndrome di Indonesia dialami (70\%-9 0\%) oleh wanita usia reproduktif dan (2\%-10\%) mengalami gejala premenstrual berat. Penelitian ini bertujuan untuk mengetahui faktor determinan yang mempengaruhi kejadian premenstrual syndrom Rumah Sakit Muhammadiyah Palembang tahun 2015. Populasi 45 wanita yang memenuhi kriteria inklusi. Pengumpulan data menggunakan kuesioner. Hasil penelitian menunjukkan bahwa responden yang mengalami PMS berjumlah $77,8 \%$ dan ada hubungan antara faktor paritas ( $p$ value 0,004, ) faktor umur ( $\mathrm{p}$ value 0,005 ), faktor status gizi ( $\mathrm{p}$ value 0,003 ), dan faktor aktifitas olahraga ( $p$ value 0,002), dengan kejadian PMS di Rumah Sakit Muhammadiyah Palembang. Analisis multivariat didapatkan tidak ada yang berinteraksi dan hasil analisis faktor dominan adalah umur wanita produktif yang beresiko dalam kejadian premenstrual syndrom dengan 0,903 artinya 90,3\% yang mengalami PMS karena umur wanita produktif. Bagi Rumah Sakit disarankan perlunya peningkatan konseling pra menstruasi. Bagi wanita usia produktif agar lebih banyak mengkonsumsi makan sumber karbohidrat dan mengurangi asupan garam. Bagi Peneliti sendiri dapat menambah wawasan serta pemahaman tentang PMS. Bagi STIK Bina Husada agar lebih memfasilitasi atau memperbanyak referensi di perpustakaan khususnya tentang penulisan ilmiah dan metodelogi penelitian, sehingga dapat menambah pustaka dan keilmuan. Bagi Peneliti selanjutnya disarankan menggunakan desain cohort dengan mempertimbangkan variabel confounding yaitu variabel tingkat pendidikan, sosial budaya dan status ekonomi.

Kata Kunci : Premenstrual Syndrom, Determinan, Wanita, Usia Produktif

\begin{abstract}
Few days before menstruation, a number of girls and women usually collection of physical, psychological and emotional symptoms which are associated with the menstrual cycle which is experienced before menstrual period or premenstrual syndrome (PMS). The syndromes that are commonly felt are breast tenderness, lower abdominal bloating, extreme fatigue, muscle soreness especially in the lower back or abdomen, changes in vaginal discharge, pimples and very strong. The occurrence of premenstrual syndrome experienced by women in their productive age in Indonesia is 70/100,000-90/100,000 (70\%-90\%) and 2/100,000$10 / 100,000$ (2\%-10\%) experiencing severe premenstrual syndrome. The purpose of the study is to know the determinant factors which inflelience premestrual syndrome in muhammadiyah hospital palembang 2015. The population is 45 kriteria inklusi, respondents questionnaire was used in collecting the data. The result of the study indicated there was a correlations between the factors of parity $(P$ value 0,004$)$, age $(P$ value $0,005)$, nutritional status ( $P$ value 0,003$)$, and sports activity ( $P$ value 0,002), with the occurrence of PMS at Muhammadiyah Hospital Palembang. Multivariate analysis showed that there was no interaction
\end{abstract}


and analytical result showed that the dominant factor was the age of productive women who were at risk in experiencing PMS because premenstrual syndrome with 0,903 which means that 90,3\% of women were experiencing PMS because they were at their productive age. For recommendation, the hospital is suggested to improve the pre menstruation counseling. Then, women at their productive age should consume high carbohydrate foods and reduce salt understanding about PMS. Bina Husada Higher School is also expected to facilitate and enrich the refrences especially on scientific writing and research methodology in its library. For further research suggested using a cohort design taking into account the confounding variable is the variable level of education, socio cultural and economic status.

Keywords: Premenstrual Syndrome, Determinant, Woman, Productive Age

\section{PENDAHULUAN}

Sejumlah kecil wanita merasa PMS sangat menganggu, sehingga aktivitas normal terhambat untuk beberapa hari selama hari -hari menstruasi. Ciri khas dari kelainan ini adalah keluhan muncul saat menjelang haid dan akan hilang dengan sendirinya begitu haid datang. Sindrom Pramenstruasi (Pramenstrual Syndrome (PMS)) di mulai fase luteal, yakni pada sekitar hari ke 7 dan ke - 10 sebelum menstruasi. Wanita dapat merasakan peningkatan kreativitas dan energi fisik serta mental, gejala negatif berhubungan dengan oedema (abdomen kembung, oedema pada ekstremitas bawah, nyeri tekan payudara dan peningkatan berat badan) atau ketidakstabilan emosi (depresi, tiba-tiba menangis, iritabilitas, sering panik dan tidak mampu bekonsentrasi). Nyeri kepala, keletihan dan nyeri punggung merupakan keluhan umum (Bobak, 2004).

Survey menunjukkan bahwa premenstrual syndrome (PMS) merupakan masalah kesehatan umum yang paling banyak dilaporkan oleh wanita usia reproduksi, pada saat ini diperkirakan prevalensi dari gejala klinis yang berarti adalah sekitar 12,6\%-31\% dari wanita yang mengalami menstruasi. Studi epidemoilogi menunjukkan kurang lebih $20 \%$ dari wanita usia reproduksi mengalami gejala $P M S$ sedang sampai berat. Dalam suatu penelitian terhadap 384 wanita yang berusia 15 tahun melaporkan bahwa mereka mengalami PMS adalah sebanyak 14\% (Maulana, 2008).

Angka kejadian premesntrual Syndrome di Indonesia menurut Lestari 2013. Premesntrual syndrome dialami 70/100000-90/100000 (70\%$90 \%$ ) oleh wanita usia reproduktif dan 2/100000-
10/100000 (2\%-10\%) mengalami gejala premesntrual berat.

Menurut data dari Rekam Medis di Rumah Sakit Muhammadiyah Palembang menyebutkan Pada Tahun 2011 kasus Pre-Menstrual Syndrome sekitar $40 \%$ dialami oleh wanita berusia $14-50$ tahun. Tahun 2012 kasus Pre-Menstrual Syndrome sekitar $47 \%$ dialami oleh wanita berusia 20-35 tahun. Dan pada tahun 2013 menunjukkan, Premenstrual Syndrome dialami 50\% wanita dengan usia 20-35 tahun yang datang ke Poli Kebidanan Rumah Sakit Muhammadiyah Palembang.

Sindrom ini biasanya lebih mudah terjadi pada wanita yang lebih peka terhadap perubahan harmonal dalam siklus haid. Akan tetapi ada beberapa faktor yang meningkatkan risiko terjadinya PMS yaitu paritas, umur, status gizi dan aktifitas olahraga (Eva, 2010).

Berdasarkan uraian diatas peneliti tertarik untuk melakukan penelitian dengan judul "Analisis Determinan Premenstrual Syndrome (PMS) Terhadap Wanita Usia Produktif Di Poli Obstetri Dan Gynekologi Rumah Sakit Muhammadiyah Palembang Tahun 2015"

\section{METODE PENELITIAN}

Desain penelitian ini menggunakan metode penelitian kuantitatif melalui pendekatan Cross Sectional dimana variabel independen dan variabel dependen dikumpulkan dalam waktu yang bersamaan (Arikunto,2006).

Populasi dalam penelitian ini adalah seluruh wanita yang telah mengalami menstruasi (wanita usia produktif) dan tidak sedang hamil yang mengunjungi Poli obstetri dan gynecology Rumah Sakit Muhammadiyah Palembang yang berjumlah 51 orang (Notoatmodjo, 2010) 
Jurnal Kebidanan : Jurnal Medical Science Ilmu Kesehatan Akademi Kebidanan Budi Mulia Palembang Volume.8 No.1, Juni 2018

Sampel penelitian ini sebanyak 45 responden adalah perwakilan dari populasi yang akan diteliti dalam suatu penelitian. Tehnik sampel yang digunakan adalah accidental sampling yang berdasarkan pengumpulan data terhadap sejumlah sampel yang ditemui (Ariani, 2014).

Penelitian ini dilaksanakan pada Desember 2015. Pengambilan data dilaksanakan di Poli Obstetri dan Gynekology Rumah Sakit Muhammadiyah Palembang pada tanggal 30 Januari - 06 Februari 2015.

Pada penelitian ini analisa univariat dilakukan terhadap tiap variabel dari hasil penelitian. Pada umumnya dalam analisa hanya menghasilkan distribusi dari tiap variabel (Hastono, 2010)

Analisa bivariat merupakan analisa hasil dari variabel-variabel bebas yang diduga mempunyai hubungan dengan variabel terkait. Analisa data yang digunakan adalah tabel silang. Untuk menguji hipotesa dilakukan analisa statistik dengan menggunakan uji Khi Kuadrat (Chi-Square) pada tingkat kemaknaan 95\% ( $<<0,05)$ sehingga dapat diketahui ada tidaknya hubungan yang bermakna secara statistic.

Penelitian ini menggunakan regresi logistik untuk mengetahui hubungan antara variabel independent dan satu variabel dependen. Dengan memakai persamaan Multiregresi (Riyanto, 2012):

$$
y=a+b 1 \times 1+b 2 \times 2+b 3 \times 3+b 4 \times 4
$$

Analisa faktor adalah salah satu metode statistik multivariat yang mencoba analisis faktor menemukan hubungan (interrelationship) atau sejumlah variabel-variabel yang saling independen satu sama lain, sehingga dapat dibuat satu atau beberapa kumpulan variabel yang lebih sedikit dari jumlah variabel awal. Aplikasi dari persamaan model tersebut adalah untuk memprediksi probabilitas Kejadian PMS dengan menghitung nilai Atributable Fraction (AF) (Santoso. 2010)

\section{HASIL DAN PEMBAHASAN}

\section{Hubungan Paritas dengan Premenstrual Syndrome.}

Tabel 1. Distribusi Responden Berdasarkan Paritas dengan Premenstrual Syndrome di Poli Obstetri dan Gynekology Rumah Sakit Muhammadiyah Palembang Tahun 2015

\begin{tabular}{|c|c|c|c|c|c|c|c|c|c|}
\hline \multirow{3}{*}{$\begin{array}{r}\text { Variabel } \\
\text { Paritas }\end{array}$} & \multicolumn{4}{|c|}{ Premenstrual Syndrome } & \multicolumn{2}{|c|}{ Jumlah } & \multirow{3}{*}{$\begin{array}{c}\rho . \\
\text { Value }\end{array}$} & \multirow[t]{3}{*}{ OR } & \multirow{3}{*}{$\begin{array}{c}95 \% \\
\text { CI }\end{array}$} \\
\hline & \multicolumn{2}{|c|}{ Ya } & \multicolumn{2}{|c|}{ Tidak } & \multirow[b]{2}{*}{$\mathrm{N}$} & \multirow[b]{2}{*}{$\%$} & & & \\
\hline & $\mathrm{n}$ & $\%$ & $\mathrm{n}$ & $\%$ & & & & & \\
\hline Multipara & 22 & 95.7 & 1 & 4.3 & 23 & 100 & 0,004 & 15.231 & 1.727 \\
\hline & & & & & & & & & - \\
\hline Primipara & 13 & 59.1 & 9 & 40.9 & 22 & 100 & & & 134.304 \\
\hline Jumlah & 35 & & 10 & & 45 & & & & \\
\hline
\end{tabular}

Hasil analisis bahwa ada sebanyak 23 responden dengan paritas multipara terdapat $(95,7 \%)$ yang mengalami premesntrual syndrome dan dari 22 responden dengan paritas primipara terdapat $(59,1 \%)$ yang ya mengalami premesntrual syndrome.

Hasil uji statistic di peroleh nilai $\mathrm{P}=0,004$, maka disimpulkan bahwa secara statistik pada alpa $5 \%$ ada hubungan yang signifikan antara paritas dengan premenstrual syndrome terhadap wanita usia produktif di Poli Obstetri dan Gynekology Rumah Sakit Muhammadiyah Palembang Tahun 2015. Dan dari analisis uji keeratan hubungan diperoleh nilai OR :15.231 artinya yang termasuk wanita paritas multipara mempunyai resiko 15 kali untuk mengalami premenstrual syndrome di bandingkan dengan wanita paritas primipara.

Paritas adalah jumlah anak yang dilahirkan oleh ibu, beresiko tinggi jika melahirkan $\geq 3$ orang anak dan beresiko rendah apabila $<3$ orang anak. Karena endomemetrium belum sempat sembuh ${ }^{1}$ Wanita yang pernah melahirkan (premenstrual syndrome semakin berat setelah melahirkan beberapa anak, terutama bila pernah mengalami kehamilan dengan komplikasi seperti toksima) (Eva, 2010)

Hasil penelitian dari Irayani (2007)tentang faktor-faktor yang mempengaruhi terjadinya premesntrual syndrome pada wanita usia subur di dapat faktor paritas ditemukan $12,5 \%$ responden belum punya anak $62,5 \%$ responden dengan paritas 1-2 orang dan 25\% dengan paritas 3-4 orang.

Dari hasil penelitian Anggrajani dkk (2011) bahwa hasil penelitian terhadap 84 sampel, sebanyak 36 subyek penelitian $(42,9 \%)$ belum pernah melahirkan. Hasil uji chi-square dengan nilai $P<\boldsymbol{\alpha}(0,079)$ menunjukkan terdapatnya hubungan paritas dan premenstrual syndrome pada dokter perempuan di fakultas kedokteran Universitas Airlangga. Responden yang paritas tinggi mempunyai 0,193 kali lebih berpeluang mengalami premesntrual syndrome dari pada paritas rendah.

Berdasarkan hasil penelitian dan teori yang ada maka peneliti berpendapat hal ini tidak sejalan dengan penelitian terdahulu, bahwa wanita yang telah melahirkan anak hidup beberapa kali, dimana 
persalinan tersebut tidak lebih dari lima kali (paritas multipara) yang pernah mengalami kehamilan dengan komplikasi toksima termasuk dalam kategori risiko tinggi mengalami premenstrual syndrome dari pada wanita yang telah melahirkan sebanyak satu kali (paritas primipara).

2. Hubungan Umur dengan Premenstrual Syndrome.

Tabel 2. Distribusi Responden Berdasarkan Umur dengan Premenstrual Syndrome di Poli Obstetri dan Gynekology Rumah Sakit Muhammadiyah Palembang Tahun 2015

\begin{tabular}{|c|c|c|c|c|c|c|c|c|c|}
\hline \multirow{3}{*}{$\begin{array}{l}\text { Variabel } \\
\text { Umur }\end{array}$} & \multicolumn{4}{|c|}{ Premenstrual Syndrome } & \multicolumn{2}{|c|}{ Jumlah } & \multirow{3}{*}{$\begin{array}{c}\rho . \\
\text { Va } \\
\text { lue }\end{array}$} & \multirow{3}{*}{$\begin{array}{l}\mathbf{O} \\
\mathbf{R}\end{array}$} & \multirow{3}{*}{$\begin{array}{c}95 \% \\
\text { CI }\end{array}$} \\
\hline & \multicolumn{2}{|c|}{ Ya } & \multicolumn{2}{|c|}{ Tidak } & & & & & \\
\hline & $\mathrm{n}$ & $\%$ & $\mathrm{n}$ & $\%$ & $\mathrm{~N}$ & $\%$ & & & \\
\hline Produktif & 28 & 90.3 & 3 & 9.7 & 31 & $\begin{array}{c}10 \\
0\end{array}$ & $\begin{array}{l}0,0 \\
05\end{array}$ & $\begin{array}{c}9 . \\
33 \\
3\end{array}$ & $\begin{array}{l}1.911- \\
45.583\end{array}$ \\
\hline $\begin{array}{l}\text { Tidak } \\
\text { Produktif }\end{array}$ & 7 & 50.0 & 7 & 50.0 & 14 & $\begin{array}{c}10 \\
0\end{array}$ & & & \\
\hline Jumlah & 35 & & 10 & & 45 & & & & \\
\hline
\end{tabular}

Hasil analisis bahwa ada sebanyak 31 responden dengan umur wanita produktif terdapat (90,3\%) yang mengalami premesntrual syndrome dan dari 14 responden dengan umur wanita yang tidak produktif terdapat $(50,0 \%)$ yang ya mengalami premesntrual syndrome .

Hasil uji statistik di peroleh nilai $p=0,005$, maka disimpulkan bahwa secara statistik pada alpa $5 \%$ ada hubungan yang signifikan antara umur dengan premenstrual syndrome terhadap wanita usia produktif di Poli Obstetri dan Gynekology Rumah Sakit Muhammadiyah Palembang Tahun 2015. Dan dari analisis uji keeratan hubungan diperoleh nilai $\mathrm{OR}=9,333$ artinya umur wanita yang produktif mempunyai resiko 9 kali untuk mengalami premenstrual syndrome di bandingkan dengan umur yang tidak produktif.

Premenstrual syndrome (PMS) dapat dihubungkan dengan siklus ovulasi, karena itu gejala-gejala $P M S$ dapat terjadi kapan saja setelah menarche dan berlanjut hingga ovulasi berhenti pada saat menopause. Sebagian besar pasien yang mencari pengobatan untuk $P M S$ berusia antara 30 sampai 45 tahun, meskipun banyak wanita melaporkan mengalami gejalagejala PMS lebih awal (Manuaba, 2002).

Premenstrual Syndrome terjadi pada sekitar 70-90\% wanita pada usia subur. lebih sering ditemukan pada wanita berusia 20-40 tahun, di jelaskan usia produktif $20-<35$ tahun dan usia tidak produktif < 20 - > 35 (Nugroho, 2014)

Hasil penelitian didapatkan dari Nashruna dkk (2012) dari 119 responden sebagian besar responden dengan umur 21-25 tahun, 31-35 tahun, dan 36-40 tahun dengan masing-masing sebanyak 31 responden $(26,1 \%)$ dan sebagian kecil responden dengan umur 26-30 tahun sebanyak 26 responden $(21,8 \%)$.

Dari hasil penelitian Anggrajani (2011), terhadap 84 sampel, maka umur subyek penelitian terbanyak adalah berkisar 25 - 34 tahun yaitu berjumlah 63 orang $(75 \%)$. Hasil uji chi-square dengan nilai $P<\boldsymbol{\alpha}(0,018)$ menunjukkan terdapatnya hubungan umur dan premenstrual syndrome pada dokter perempuan di fakultas kedokteran Universitas Airlangga. Responden yang ber umur 25- 34 tahun mempunyai 0,258 kali lebih berpeluang mengalami premesntrual syndrome dari pada usia muda.

Berdasarkan hasil penelitian dan teori yang ada maka peneliti berpendapat bahwa penelitian ini sejalan dengan penelitian terdahulu, dari 45 responden ada 31 responden yang termasuk umur wanita produktif beresiko tinggi terhadap kejadian premenstrual syndrom karena umur produktif masih mengalami menstruasi sehingga sebelum terjadinya menstruasi wanita sering mengalami gejala PMS maka dari seluruh faktor yang mempengaruhi

Premenstrual syndrome hanya faktor umur yang paling dominan terhadap kejadian PMS.

\section{Hubungan Status Gizi dengan Premenstrual Syndrome}

Tabel 3.Distribusi Responden Berdasarkan Status Gizi dengan Premenstrual Syndrome di Poli Obstetri dan Gynekology Rumah Sakit Muhammadiyah Palembang Tahun 2015

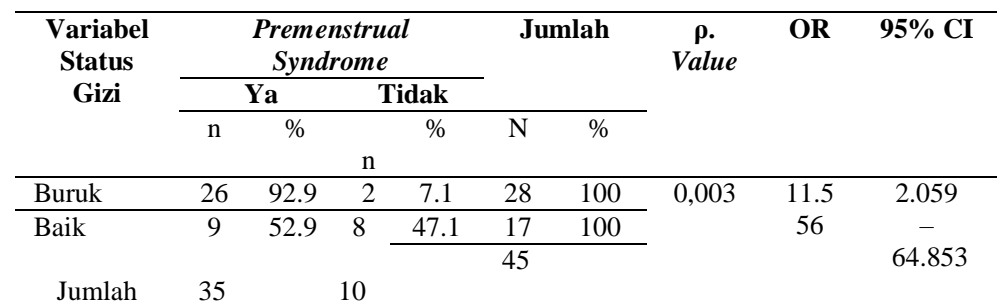

Hasil analisis bahwa ada sebanyak 28 responden dengan status gizi yang buruk terdapat $(92,9 \%)$ yang mengalami premesntrual syndrome dan dari 17 responden dengan status gizi yang baik terdapat $(52,9 \%)$ yang mengalami premesntrual syndrome. 
Hasil uji statistik di peroleh nilai $\mathrm{p}=0,003$, maka disimpulkan bahwa secara statistik pada alpa $5 \%$ ada hubungan yang signifikan antara status gizi dengan premenstrual syndrome terhadap wanita usia produktif di Poli Obstetri dan Gynekology Rumah Sakit Muhammadiyah Palembang Tahun 2015. Dan dari analisis uji keeratan hubungan diperoleh nilai $\mathrm{OR}=11,556$ artinya yang termasuk wanita status gizi buruk mempunyai resiko 11 kali untuk mengalami premenstrual syndrome di bandingkan dengan wanita status gizi baik.

Wanita yang mengkonsumsi makanan rendah kandungan, mineral besi, kalsium, dan magnesium memiliki resiko terkena sindrom pramenstruasi lebih tinggi dibandingkan wanita yang mengkonsumsi makanan yang cukup mengandung mineral besi, kalsium dan magnesium banyak terdapat pada bahan pangan sumber hewani. Dari sebuah studi diketahui bahwa wanita yang rutin menambah suplemen kalsium (1000 $\mathrm{mg} / \mathrm{hari})$ atau magnesium $(250 \mathrm{mg} /$ hari) pada pola makannya,lebih kecil beresiko mengalami PMS minum air minimal 8 gelas sehari untuk membantu pengangkutan vitamin dan mineral ke seluruh bagian tubuh dan memproduksi enzim pencernaan yang membantu proses tubuh. Minum dengan jumlah yang cukup dapat mengurangi pembengkakan, retensi air, dan gejala sindrom pramenstruasi lainnya (Devi, 2009).

Menurut penelitian Devi (2009) Bahwa hasil penelitian dari 75 responden sebesar $53,66 \%$ memiliki indeks massa tubuh antara kurang dari 18,5 yaitu dengan status gizi kurang. Sebesar $41.18 \%$ subjek penelitian yang tidak mengalami sindrom pramenstruasi.

Dari hasil penelitian Magdalena(2007), bahwa hasil penelitian terhadap 371 sampel, kurus 14 orang $27,5 \%$, normal 86 orang $39,4 \%$, overweight 33 irang $60,0 \%$ dan obesitas 37 orang $78,7 \%$. Hasil uji chi-square dengan nilai $P<\boldsymbol{\alpha}$ $(0,000)$ menunjukkan terdapatnya hubungan status gizi dan premenstrual syndrome pada mahasiswa akademi kebidanan Pemerintah Kabupaten Kudus. Responden yang obesitas mempunyai 2,192 kali lebih berpeluang mengalami premesntrual syndrome dari pada yang berat badan nya normal.

Berdasarkan hasil penelitian dan teori yang ada maka peneliti berpendapat bahwa penelitian ini sejalan dengan penelitian terdahulu bahwa status gizi yang buruk dapat mengakibatkan kejadian premenstrual syndrome karena Faktor kebiasaan makan seperti tinggi gula, garam, kopi, teh, coklat, minuman bersoda, produk susu, makanan olahan, memperberat gejala PMS maka dari itu penderita
PMS harus mengurangi konsumsi makanan tersebut.

4. Hubungan Aktifitas Olahraga dengan Premenstrual Syndrome

Tabel 4. Distribusi Responden Berdasarkan Aktifitas Olahraga Dengan Premenstrual Syndrome di Poli Obstetri Gynekology Rumah Sakit Muhammadiyah Palembang Tahun 2015

\begin{tabular}{|c|c|c|c|c|c|c|c|c|c|}
\hline \multirow{3}{*}{$\begin{array}{l}\text { Variabel } \\
\text { Aktifitas } \\
\text { Olahraga }\end{array}$} & \multicolumn{4}{|c|}{ Premenstrual Syndrome } & \multirow{3}{*}{$\begin{array}{c}\text { Jmlh } \\
\mathrm{N} \\
\end{array}$} & \multirow{2}{*}{$\begin{array}{c}\text { p. } \\
\text { Value }\end{array}$} & \multirow{2}{*}{\multicolumn{2}{|c|}{ OR }} & \multirow{3}{*}{$\begin{array}{c}95 \% \\
\text { CI }\end{array}$} \\
\hline & \multicolumn{2}{|c|}{ Ya } & \multicolumn{2}{|c|}{ Tidak } & & & & & \\
\hline & $\mathrm{n}$ & $\%$ & $\mathrm{n}$ & $\%$ & & $\%$ & & & \\
\hline \multirow[t]{2}{*}{ Kurang } & 24 & 96 & 1 & 4 & 25 & 100 & 0,002 & 19. & 2.207 \\
\hline & & & & & & & & 636 & - \\
\hline Cukup & 11 & 55 & 9 & 45 & 20 & 100 & & & 174.7 \\
\hline Jumlah & 35 & & 10 & & 45 & & & & 14 \\
\hline
\end{tabular}

Hasil analisis bahwa ada sebanyak 25 responden dengan aktifitas olahraga yang kurang terdapat $(96,0 \%)$ yang mengalami premesntrual syndrome dan dari 20 responden dengan aktifitas olahraga yang cukup terdapat $(55,0 \%)$ yang mengalami premesntrual syndrome.

Hasil uji statistik di peroleh nilai $\mathrm{p}=0,002$, maka disimpulkan bahwa secara statistik pada alpa $5 \%$ ada hubungan yang signifikan antara aktifitas olahraga dengan premenstrual syndrome terhadap wanita usia produktif di Poli Obstetri dan Gynekology Rumah Sakit Muhammadiyah Palembang Tahun 2015. Dan dari analisis uji keeratan hubungan diperoleh nilai $\mathrm{OR}=19.636$ artinya wanita aktifitas olahraga yang kurang mempunyai resiko 19 kali untuk mengalami premenstrual syndrome di bandingkan dengan wanita aktifitas olahraga yang cukup.

Menurut WHO yang dimaksud dengan aktivitas fisik adalah kegiatan yang dilakukan paling sedikit 10 menit tanpa henti. Aktivitas fisik dibagi atas 3 tingkatan yakni aktivitas fisik ringan, sedang, dan berat. Aktivitas fisik ringan adalah segala sesuatu yang berhubungan dengan menggerakkan tubuh, aktivitas fisik sedang adalah pergerakan tubuh yang menyebabkan pengeluaran tenaga cukup besar, dengan kata lain adalah bergerak yang menyebabkan nafas sedikit lebih cepat dari biasanya, sedangkan aktivitas fisik berat adalah pergerakan tubuh yang menyebabkan pengeluaran tenaga cukup banyak (pembakaran kalori) sehingga nafas jauh lebih cepat dari biasanya.Kurang berolahraga dan aktivitas fisik menyebabkan semakin beratnya PMS (Eva, 2010)

Dari hasil penelitian Lestari (2013), bahwa hasil penelitian terhadap 61 siswi, hasil yang 
peneliti dapatkan dari aktifitas olahraga yang dilakukan oleh remaja putri ditemukan hanya 16,4\% (10 siswi) yang tidak mengalami PMS sedangkan yang mengalami PMS berat sebanyak $18 \%$ (11 siswi) dan yang mengalami PMS ringan sebanyak $65,6 \%$ (40 siswi) dengan demikian banyak siswi yang tidak melakukan olahraga teratur mengalami Pemenstrual Syndrome. Hasil uji chi-square dengan nilai $P<\boldsymbol{\alpha}(0,000)$ menunjukkan terdapatnya ada hubungan antara aktifitas olahraga dengan kejadian Premenstrual Syndrome.

Hasil penelitian ini sejalan dengan Nashruna dkk,(2012) hasil analisa statistik dengan menggunakan Chi Square pada derajat kebebasan (df) 1 dan taraf signifikasi 95\% didapatkan hasil : $P$ value $0,008<0,05$ dan $\mathrm{x}^{2}$ hitung $(7.149)>\mathrm{x}^{2}$ hal ini menunjukan ada hubungan yang bermakna antara hubungan yang hubungan aktivitas olahraga dengan kejadian sindrom pramenstruasi di Desa Pucangmiliran Tulung Klaten. Ood Ratio (OR) 2.756 yang berarti bahwa responden yang tidak rutin melakukan olahraga berpeluang mengalami sindrom pramenstruasi 2.756 kali lebih besar dibandingkan dengan responden yang rutin melakukan olahraga.

Berdasarkan hasil penelitian dan teori yang ada maka peneliti berpendapat bahwa penelitian ini sejalan dengan penelitian terdahulu bahwa aktifitas olahraga yang kurang dapat mengakibatkan kejadian premenstrual syndrome berat karena difisiensi endorfin dalam tubuh dapat tubuh dapat mengakibatkan sindrom pramenstruasi, jika aktifitas olahraga kurang maka tidak dapat merangsang hormon endorfin keluar sehingga tidak menimbulkan rasa tenang saat sindrom pramenstruasi itu terjadi.

\section{Hasil Analisis Faktor Dominan}

Analisa faktor adalah salah satu metode statistik multivariat yang mencoba analisis faktor menemukan hubungan (interrelationship) atau sejumlah variabel-variabel yang saling independen satu sama lain, sehingga dapat dibuat satu atau beberapa kumpulan variabel yang lebih sedikit dari jumlah variabel awal (Santoso. 2010)

Berdasarkan hasil analisis faktor dominan yang diperoleh, maka kontribusi wanita paritas terhadap kejadian PMS pada responden didapatkan Nilai P umur wanita adalah 0,903, artinya diperkirakan 90,3\% responden yang mengalami PMS karena umur wanita produktif. Nilai AFP umur wanita adalah 0,087 , artinya diperkirakan 87 $\%$ mengalami PMS dari seluruh populasi terjadi pada umur wanita produktif. Kontribusi umur wanita terhadap kejadian PMS adalah 6,76\%, artinya apabila responden umur wanita tidak produktif, maka kejadian PMS dapat diturunkan dari $77,8 \%$ menjadi $6,76 \%$.

\section{KESIIMPULAN}

Berdasarkan hasil penelitian yang telah dilakukan pada 45 responden yaitu wanita usia produktif di Rumah Sakit Muhammadiyah Palembang Tahun 2015, maka dapat ditarik kesimpulan sebagai berikut :

Distribusi frekuensi responden yang termasuk premenstrual syndrome sebanyak $77,8 \%$ sedangkan yang tidak termasuk sebanyak $22,2 \%$. Paritas multipara yang disebabkan komplikasi tosima sebanyak $51,1 \%$, umur produktif sebanyak $28,9 \%$, status gizi yang buruk sebanyak $62,2 \%$, dan aktifitas olahraga yang kurang sebanyak 55,6 $\%$.

Ada hubungan antara paritas dengan premenstrual syndrome.

Ada hubungan antara umur dengan premenstrual syndrome.

Ada hubungan antara status gizi dengan premenstrual syndrome.

Ada hubungan antara aktifitas olahraga dengan premenstrual syndrome.

Variabel dominan atau yang paling besar hubungannya dengan kejadian PMS adalah Umur

\section{SARAN}

Perlunya meningkatkan konseling pra menstruasi bagi wanita usia reproduktif menyarankan lebih banyak mengkonsumsi makanan sumber karbohidrat yang kaya akan serat seperti sayur dan buah buahan. Selain itu mengurangi konsumsi makanan bergaram dan makanan manis agar gejala sindrom premenstruasi dapat dikurangi

Dapat menambah wawasan, Pengetahuan serta Pemahaman tentang determinan wanita usia produktif dengan premenstrual syndrome (PMS) di Poli Obstetri dan Gynekology Rumah Sakit Muhammadiyah Palembang.

Diharapkan lebih memfasilitasi atau memperbanyak referensi di perpustakaan

Disarankan peneliti selanjutnya menggunakan desain cohort dengan mempertimbangkan variabel confounding yaitu variabel tingkat pendidikan, sosial budaya dan status ekonomi.

\section{DAFTAR PUSTAKA}

Anggrajani, Fenny, (2011) 
Jurnal yang berjudul "Korelasi Faktor Resiko Dengan Derajat Keparahan Premenstrual Syndrome Pada Dokter Perempuan "Hal. 6. (http://Journal.unair .ac.id/ diakses 30 Nov 2014)

Ariani, Ayu, Putri (2014) Aplikasi Metodelogi Penelitian Kebidanan dan Kesehatan Reproduksi, Nuha Medika : Yogyakarta Hal. 64.

Arikunto Suharsimi. (1998).

Manajemen Penelitian, Jakarta : PT Rineka Cipta. Hal.42.

Bobak, Lowdermilk, Jensen (2004)

Keperawatan Maternitas edisi 4 jakarta : EGC. Hal : 120.

Devi, Mazarina (2009)

Jurnal, "Hubungan Kebiasaan Makanan Dengan Kejadian Sindrom Premenstruasi Pada Remaja Putri" Hal:198. (Journal.um.ac.id/index.php/teknologikejuruan/article/view/3101/461 diakses 25 Nov 2014)

Eva, Eliya (2010)

Kesehatan Reproduksi Wanita, Jakarta Hal : 75.

Hastono, Sutanto, Priyo (2010), Analisa Data, Jakarta, Hal.70. (2006),

Penerapan Statistik, Jakarta, Hal.18.

Irayani, Fahrul (2007)

"Faktor - Faktor Yang Mempengaruhi Premenstrual Syndrome" Hal.66.

Lestari Tri, (2013).

Dikutip dari jurnal, yang berjudul" Hubungan Aktifitas Olahraga Remaja Dengan Kejadian Premenstrual Syndrome Pada Siswi Di MAN 1 Bukit Tinggi" (http://ejurnal.Stikesprimanusantara.ac.id/i ndex.php/JKS-DII//article/view/127 diakses 25 Nov 2014)

Manuaba (2002)

Ilmu Kebidanan, Penyakit Kandungan \& Keluarga Berencana Untuk Pendidikan Bidan EGC : Jakarta. Hal.401.

Maulana, Razi (2008)

Di kutip dari tesis yang Berjudul "Hubungan Karakteristik Wanita usia produktif dengan Premenstrual Syndrom (PMS) dipoli Obstetri dan Gynekologi BPK-RSUD dr.Zainal Abidin Benda Aceh"

Nashruna Ifana, Maryatun, Wulandari Riyani, (2012)

Jurnal,“Hubungan Aktivitas Olahraga Dan Obesitas Dengan Kejadian Sindrom Pramenstruasi Di Desa Pucangmiliran
Tulung Klaten", STIKES Aisyiyah : Surakarta, Hal : 65-67. (www.Jurnal.Stikes Aisyiyah.ac.id/index.Php/gaster/article/vie w/33 diakses 04 Des 2014)

Notoatmodjo, Soekidjo, 2010.

Metodelogi Penelitian Kesehatan. PT Rineka Cipta. Jakarta, Indonesia. Hal. 15.

Nugroho, Taufan (2014),

Masalah Kesehatan Reproduksi Wanita, Yogyakarta: Nuha Medika, Hal : 251.

Riyanto, Agus, (2012),

Penerapan Analisis Multivariat dalam Penelitian Kesehatan. Nuha Medika : Yogyakarta. Hal. 134.

Santoso, Singgih, 2010.

Statistik Multivariat Konsep dan Aplikasi Dengan SPSS. PT Elex Media Komputindo, Jakarta. Hal. 45

Profil RS. Muhammadiyah Palembang, (2014).

Data Rekam Medik Rumah Sakit Muhammadiyah Wanita Usia Produktif yang Mengalami Premenstrual Sindrome Tahun 2011, 2012, 2013.

Puspitorini, Magdalena, Dyah (2007)

Jurnal yang Berjudul : "Obesitas Sebagai Faktor Resiko Terjadinya Premenstrual Syndrome Pada Mahasiswa Akademi Kebidanan Pemerintah Kabupaten Kudus Yogyakarta. Hal. 8. (http://Jurnal.UGM. ac.id/bkm/ article/view/3631 diakses 25 Nov 
